\title{
МОДЕЛИРОВАНИЕ И АНАЛИЗ КОЛЕБАНИЙ КОРПУСА ТУРБИНЫ 500 МВТ ПРИ СНИЖЕНИИ РАБОЧЕЙ ЧАСТОТЫ
}

\author{
Красников С. В. 1 , \\ ${ }^{1}$ Харьковский национальный автомобильно-дорожный университет
}

\begin{abstract}
Аннотация. Созданы модели частей и всей системы турбоагрегат-фундамент-основание с паротурбинной установкой мощностью 500 МВт. Построены геометрические и расчетные модели с подробным моделированием корпусов иилиндров низкого давления. Проведено расчеты вынужденных колебаний корпусов цилиндров низкого давления при снижении рабочей частоты. В результате расчетных исследований определены элементы с повыменными вибрачиями. В расчетах и моделировании использовался метод конечных элементов.
\end{abstract}

Ключевые слова: вибрачия; ичлиндр низкого давления; паровая турбина; метод конечных элементов; фундамент; колебания.

\section{Введение}

Энергетический комплекс большинства стран использует производство электроэнергии на тепловых и атомных электростанциях. Энергоблоки этих электростанций оборудованы тепловыми турбинами средней и большой мощности. Структурно такие турбины состоят из нескольких корпусных конструкций и единого валопровода. Вибрационный анализ подобных систем является сложной задачей. Учет особенностей системы турбоагрегатфундамент-основание при вибрационном анализе приводим к необходимости постановки и решения целого ряда научных задач. В прошлом веке при разработке первых образцов паровых турбин средней и большой мощности многие задачи, в том числе задачи вибрационного анализа, решались с помощью значительных упрощений расчетных схем и многочисленных экспериментальных исследований. В современном научном обществе основное внимание уделяется экономически целесообразным решениям, среди которых наиболее распространенными считаются численные исследования на основе новых и усовершенствованных научных методик. Первые образцы отечественных паровых турбин мощностью от 500 до 1000 МВт были разработаны харьковскими учеными и инженерами под общим руководством Косяка Юрия Фёдоровича - генерального конструктора паровых и газовых турбин ПОАТ «Харьковский турбинный завод» имени Кирова. Руководство современными решениями научных и технических задач разработки и производства паровых турбин осуществляют Левченко Е. В., Швецов В. Л.,
Гришин Н. Н. и др. Важной практической задачей является отстройка от резонанса всей системы турбоагрегат-фундамент-основание. Численное решение этой задачи имеет множество особенностей, одной из которых является сложность учета наиболее гибких корпусных элементов паровой турбины [1-4]. Решением этой задачи на основе трехмерных математических моделей занимались Журавлева А.M., Степченко А.С., Жовдак В. А. Первоначальные идеи по созданию нового типа расчетных моделей и методик вибрационных исследований предложены д.т.н. Богомоловым С.И. Полученные методики построения расчетных моделей и проведения вибрационных исследований позволяют определять конкретные места на корпусах цилиндров паровой турбины с наибольшими амплитудами колебаний, а также находить наиболее оптимальные способы устранения повышенной вибрации и оценивать конечное вибрационное состояние до проведения работ по практической реализации решений по изменению вибрационного состояния. Дальнейшие работы в этом направлении продолжил автор. Решенные на практике задачи позволили в ряде случаев не проводить дорогостоящую модернизацию по ужесточению корпусов цилиндров низкого давления турбоагрегата, заменив ее оптимальной системой дополнительных стержней и пластин жесткости. Одной из паротурбинных установок, для которых проводились работы по определению наиболее целесообразной схемы улучшения вибрационного состояния, был турбоагрегат К-500-65/3000 ХТГЗ. Эксплуатация этого турбоагрегата в результате многочислен- 
ных экспериментальных работ показала неудовлетворительное вибрационное состояние. Проведение работ по балансировке роторов не привело к желаемому результату по длительному улучшению вибрационного состояния. Однако численные исследования позволили определить истинные причины неудовлетворительное вибрационного состояния турбоагрегата. Основной причиной оказалось недостаточная жесткость фундамента турбоагрегата и наличие у фундамента опасных резонансов для нескольких режимов работы всей системы. В связи с необходимостью оперативного решения проблемы по улучшению вибрационного состояния турбоагрегата было поставлено ряд задач. Одной из задач являлось моделирование и анализ колебаний корпуса цилиндра низкого давления паровой турбины при снижении рабочей частоты.

\section{Анализ публикаций}

Паровая турбина К-500-65/3000 ХТГ3 состоит из цилиндра высокого давления и четыpeх цилиндров низкого давления. Цилиндры низкого давления имеют наиболее гибкий корпус подверженный вибрации (рис. 1). Каждый корпус цилиндров низкого давления состоит из двух выхлопных патрубков, а также технологически разделяется на верхнюю и нижнюю части. Соединение выхлопных патрубков выполнено фланцами на плоскостях симметрии. Нижние части выхлопных патрубков цилиндров низкого давления с помощью сварочных соединений жестко связаны с переходным патрубком конденсатора. Внутри корпусов цилиндров низкого давления находятся обоймы с диафрагмами пяти ступеней. Жесткость верхней половины корпусов выхлопных патрубков обеспечивается в большей степени за счет стержней и труб. Нижняя часть цилиндров низкого давления набрана большей частью из пластин в виде сотовой структуры.

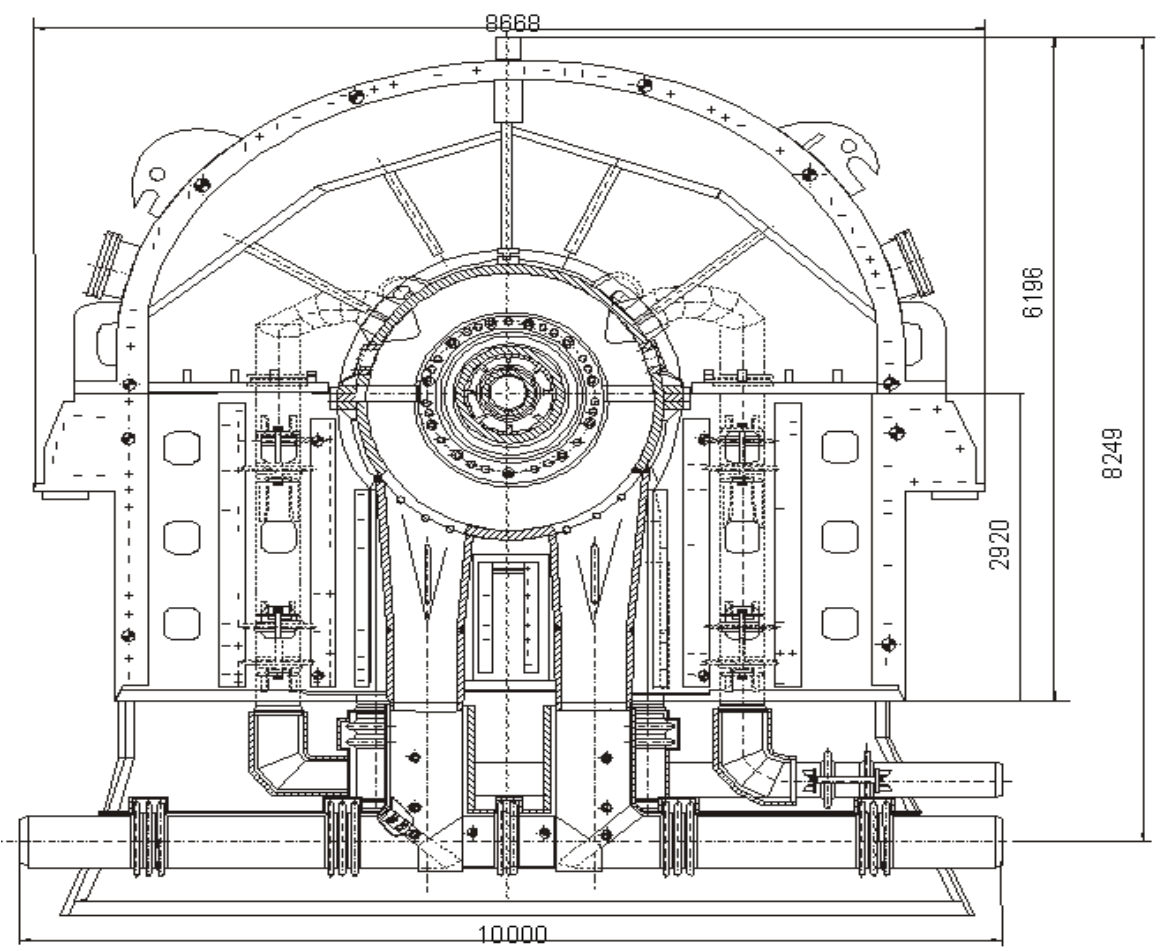

Рис. 1. Поперечный разрез цилиндра низкого давления

Подробное описание паровой турбины К-500-65/3000 ХТГЗ, а также основные особенности, основные конструкционные и научные решения в процессе ее создания и модернизации приводятся в [1-4].
Цель и постановка задачи

Цель работы заключается в определении амплитудно-частотных зависимостей вынужденных колебаний на стенках корпусов цилиндров низкого давления, а также причин повышенных уровней их вибрации. Объек- 
том исследования является корпус цилиндра низкого давления в системе турбинафундамент-основание с паровой турбиной мощностью 500 МВт. Предметом исследования являются амплитуды вынужденных колебаний корпуса цилиндра низкого давления при снижении рабочей частоты.

\section{Математическая модель}

Основной функционал задачи является разностью кинетической и потенциальной энергии и может быть представлен в следующем виде:

$$
L(t, O, q)=0
$$

где $O$ - связи паровой турбины и фундамента;

$L$ - оператор Лагранжа второго рода;

$q$ - обобщенные перемещения.

В соответствии с методом конечных элементов [5-7] выражение функционала (1) представляется в матричном виде:

$$
[M]\{\ddot{q}(t)\}+[C]\{\dot{q}(t)\}+[K]\{q(t)\}=R,
$$

где $M$-инерционная матрица;

$C$ - демпферная матрица;

$K$ - матрица жесткости;

$R$ - внешние воздействия.

Система уравнений для определения собственных частот и форм для системы определяются согласно формуле (3):

$$
\operatorname{det}\left[K-p_{j}^{2} M\right]=0 .
$$

Амплитуды вынужденных колебаний определяются с помощью метода итераций в подпространстве [5-6].

\section{Описание расчетной модели}

На основе ранее разработанной методики моделирования системы турбинафундамент-основание [8-10] построены модели железобетонного фундамента и корпусов цилиндров низкого давления (рис. 2).

Переходной патрубок и конденсаторы, как и связи между всеми элементами системы турбоагрегат-фундамент-основание учитывались в модели с помощью дополнительных масс и граничных условий [11-14]. Преимуществом предложенной автором методики является учет состояний связи от абсолютно жесткой до свободного опирания [15-20].

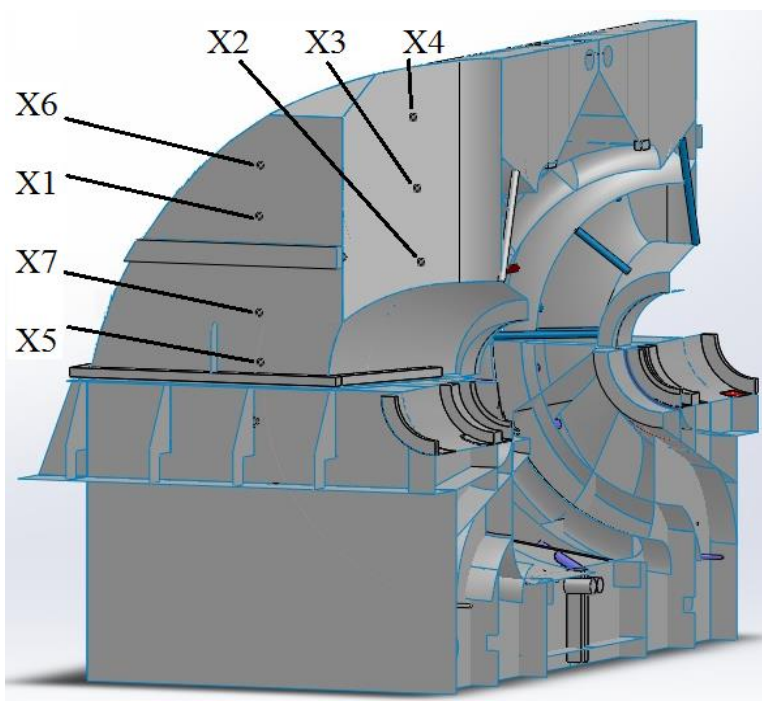

Рис. 2. Конечно-элементная модель паровой турбины К-500-65/3000 ХТГЗ

Общая расчетная конечно-элементная модель имеет 27040 узлов и 23165 конечных элементов [21].

Внешний вид половинной части модели корпуса цилиндра низкого давления приведен на рис. 2. Разрез выполнен по продольной плоскости симметрии. Внешние воздействия приложены системой равных сил по $1 \mathrm{H}$ в месте масляных подшипников роторов низкого давления, которые расположены внутри корпусов цилиндров низкого давления.

Модель фундамента конечными элементами типа стержень. Для цилиндра высокого давления, генератора и валопровода использовались в моделях системы масс.

Корпуса цилиндров низкого давления моделировались системой пластин, стержней, масс. Точки X1, X5, X6, X7 расположены на стенке, которая перпендикулярна оси валопровода; а точки X2, X3, X4 расположены над подшипником ротора низкого давления (рис. 2). Под точкой Х2 располагается верхняя крышка корпуса подшипника. Верхняя крышка подшипника моделировалась системой масс, которые распределены по балке на нижней половине подшипника. Нижняя часть подшипника ротора низкого давления встроена в нижнюю половину корпуса цилиндра низкого давления и моделировалась системой пластинчатых и стержневых конечных элементов.

Расчетные исследования амплитудночастотных характеристик колебаний

Проведены расчеты амплитуд вынужденных колебаний, указанных на рис. 2 точек 
верхних частей корпуса цилиндра низкого давления.

В расчетах использовалась модель конструкционного модального трения. Трение однородное по частотам. Его значение равно наибольшей величине из имеющегося ряда данных, взятых из результатов экспериментальных исследований и неоднократно используемого при данном типе расчетов $[7,10,14]$.

Результаты проведенных расчетов амплитудно-частотных зависимостей при снижении рабочей частоты приведены на рис. 3-9.

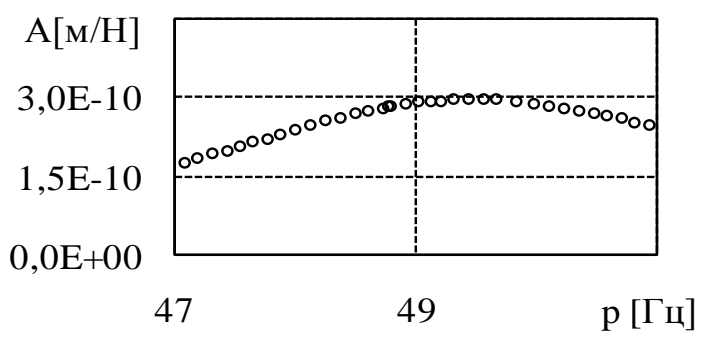

Рис. 3. Амплитуды колебаний в точке х1

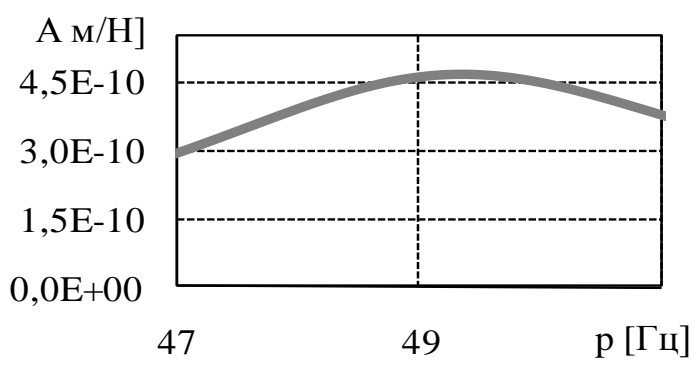

Рис. 4. Амплитуды колебаний в точке х2

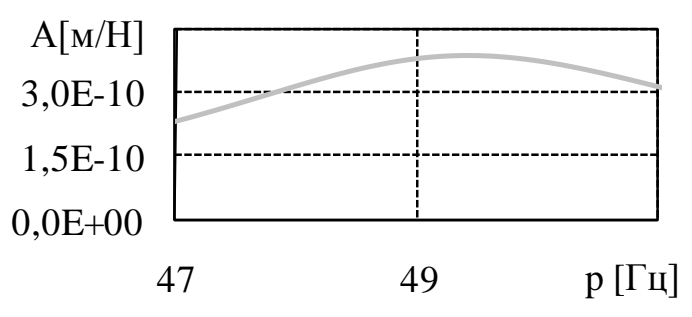

Рис. 5. Амплитуды колебаний в точке х3

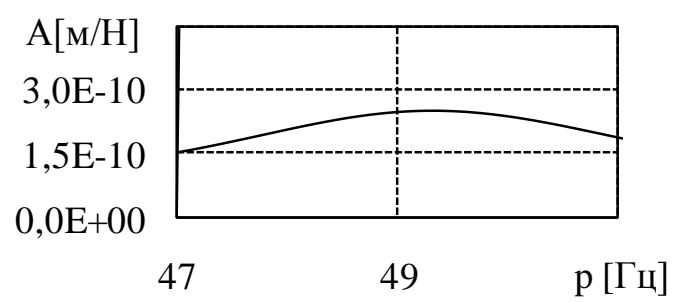

Рис. 6. Амплитуды колебаний в точке х4

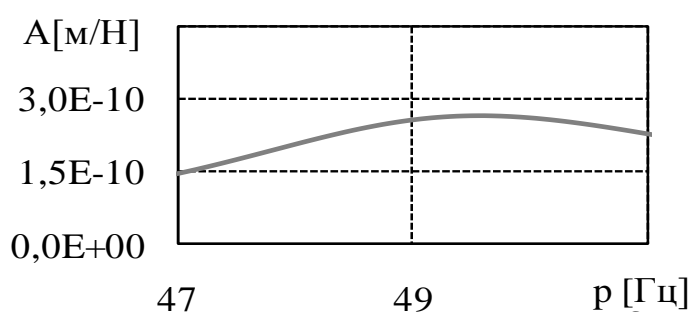

Рис. 7. Амплитуды колебаний в точке х5

Из рис. 3-9 видно, что амплитуды колебаний точек X1, X2, X3, X4, X5, X6, X7 при снижении рабочей частоты до 49 Гц увеличиваются. При дальнейшем уменьшении рабочей частоты до 48 Гц амплитуды колебаний точек X1, X2, X3, X4, X5 уменьшаются, но остаются на уровне амплитуд колебаний на стандартной рабочей частоте. При последующем снижении частоты до 47 Гц амплитуды колебаний всех указанных точек уменьшаются.

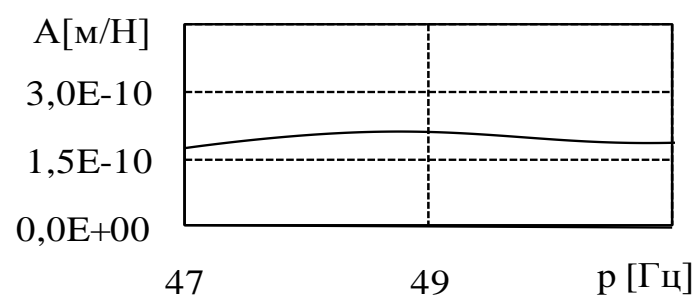

Рис. 8. Амплитуды колебаний в точке Х6

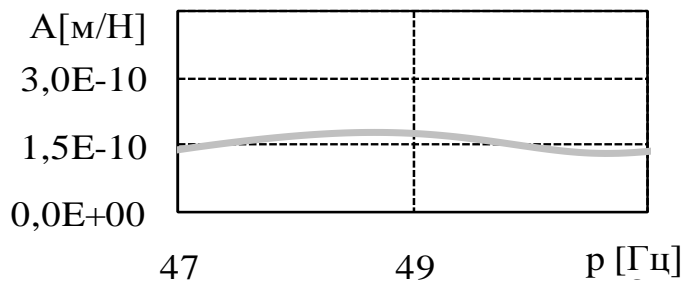

Рис. 9. Амплитуды колебаний в точке X7 
Наименьшие изменения имеют амплитуды колебаний в точках X6, X7. Наибольшие амплитуды колебаний имеет точка X2, которая наиболее близка к месту расположения встроенной в корпус опоры масляного подшипника. Увеличение амплитуд колебаний связано с тем, что при снижении рабочей частоты внешнее воздействие входит в резонанс с собственной частотой колебаний корпуса цилиндра низкого давления. Для уменьшения амплитуд колебаний, указанных на рис. 2 точек необходимо ужесточение, соответствующих стенок. В особенности требуется ужесточение стенок корпуса вблизи точки х2, которая находится в непосредственной близости от опоры подшипника валопровода.

\section{Выводы}

Анализ амплитудно-частотных характеристик вынужденных колебаний при небольшом снижении рабочей частоты показал увеличение амплитуд колебаний точек корпуса цилиндра низкого давления в связи с явлением резонанса. Дальнейшее снижение рабочей частоты сначала возвращает значения амплитуд колебаний к значениям на стандартной рабочей частоте, а затем делает их меньшими. Таким образом, вибрационное состояние корпуса при небольшой величине снижения значения рабочей частоты является неудовлетворительным. Определены стенки корпуса и конкретные места, которые требуют ужесточения конструкции.

\section{Литература}

1. Косяк Ю. Ф. и др. Паротурбинные установки атомных электростанций, ред. Ю. Ф. Косяк. М.: Энергия. 1978. 312 с.

2. Трояновский Б. М. Турбины для атомных электростанций. М.: Энергия. 1978. 182 с.

3. Левченко Е.В., Швецов В.Л., Кожешкурт И.И., Лобко А. Н. Опыт ОАО «ТурбоАтом» в разработке и модернизации турбин для АЭС. СПб,: Энергетические и теплотехнические проиессы и оборудование. 2010. № 3. С.5-11.

4. Субботин В. Г., Левченко Е. В., Швецов В. Л. Паровые турбины ОАО "Турбоатом" для тепловых электростанций. Харьков: Вестник Наи. техн. ун-та "ХПИ". 2009. № 3. С. 6-17.

5. Еременко С. Ю. Методы конечных элементов в механике деформируемых тел. Харьков: Основа. 1991. 271 с.

6. Галлагер Р. Метод конечных элементов. Основы. М.: Мир. 1984. 428 с.
7. HITACHI. Turbine and Generator Foundation Design and construction \& recommendation. Tokyo: Japan. 2009. 104 p.

8. Назаренко С. А., Ткачук Н. А. Обзор некоторых ключевых направлений исследований ученых НТУ « ХПИ» в области динамики конструкций. Харків: Вісник НTУ «ХПI». 2017. № 39. С.49-56.

9. Ларін А., Чумаченко О. Співпраця запорізьких авіадвигунобудівних підприємств 3 провідними вченими України в галузі динамічної міцності в 1950-1970-х рр. Харків: Дослідження з історії техніки. 2016. № 23. C.72-78.

10. Жовдак В. О., Красников С. В., Степченко О. С. Решение задачи статистической динамики машиностроительных конструкций с учетом случайного изменения параметров. Харків: Проблемы машиностроения. 2004. Т.7, № 3. С. $39-47$.

11.Zhiqiang $\mathrm{Hu}$, Wei Wang, Puning Jiang, Qinghua Huang, Jianhua Wang, Sihua Xu, Jin He and Lei Xiao. A Seismic Analysis on Steam Turbine Considering Turbine and Foundation Interaction. Düsseldorf: ASME Turbo Expo 2014: Turbine Technical Conference and Exposition. 2014. no. V01BT27A041. P. 1-8.

12. Alan Turnbull. Corrosion pitting and environmentally assisted small crack growth. Proceedings. Mathematical, Physical, and Engineering Sciences. London:The Royal Society. 2014. no. 20140254. P. 1-19.

13. Chowdhury Indrajit, Dasguptu P. Shambhu Dynamics of Structure and foundation a unified approach. Leiden: CRC Press. 2009. 616 p.

14. Рунов Б. Т. Исследование и устранение вибрации паровых турбоагрегатов. М.: Энергоиздат. 1982. $352 \mathrm{c}$.

15. Yu M., Feng N., Hahn E. J. An equation decoupling approach to identify the equivalent foundation in rotating machinery using modal parameters. Journal of Sound and Vibration. 2016. Vol. 365. P. 182-198.

16. Xu X. P., Han Q. K., Chu F. L. Nonlinear vibration of a generator rotor with unbalanced magnetic pull considering both dynamic and static eccentricities. Archive of Applied Mechanics. 2016. Vol. 86. P. 1521-1536.

17. Jalali M. H., Ghayour M., Ziaei Rad S., Shahriari B. Dynamic analysis of a high speed rotorbearing system. Measurement: Journal of the International Measurement Confederation. 2014. Vol. 53. P. 1-9.

18. Zhang Yang, Yanlong Jiang, Guoyuan Zhang Bending fault evaluation for the HP-IP rotor system of the nuclear steam turbine based on the dynamic model. Journal of Vibroengineering. 2017. Vol. 19. P. 3364-3379.

19. Minli Yu, Ningsheng Feng, Eric J. Hahn Corrigendum to" An equation decoupling 
approach to identify the equivalent foundation in rotatin $\mathrm{g}$ machinery using modal parameters" $J$. Sound Vib. 2016. Vol. 365. P.182 - 198.

20. Minli Yu, Jike Liu, Ningsheng Feng, Eric J. Hahn Experimental evaluation of a quasi-modal parameter based rotor foundation identification technique . J. Sound Vib. 2017. Vol. 411. P. 165 192.

21. Красніков С. В. Моделирование и анализ вибрационных характеристик корпуса паровой турбины большой мощности. Харків: Вісник HТУ «XПI». 2017. № 39. С.23-26.

\section{References}

1. Kosyak Yu. F. and other (1978). Paroturbinnye ustanovki atomnykh elektrostantsii, red. Kosyak Yu. F. [Steam turbine installations of atomic power plants], Moscow, Energiya. 312 [in Russian].

2. Troyanovskii B. M. (1978). Turbiny dlya atomnykh elektrostantsii [Turbines for nuclear power plants], Moscow, Energiya. 182 [in Russian].

3. Levchenko E. V., Shvetsov V. L., Kozheshkurt I.I., Lobko A.N. (2010). Opyt OAO « TurboAtom» v raz-rabotke i modernizatsii turbin dlya AES [Experience of OJSC "TurboAtom" in the development and modernization of turbines for nuclear power plants.], Energeticheskie $i$ teplotekhnicheskie protsessy $i$ oborudovanie. SantPeterburg. 3, 5-11 [in Russian].

4. Subbotin V. G., Levchenko E. V., Shvetsov V. L. (2009). Parovye turbiny OAO "Turboatom" dlya teplovykh elektrostantsii [Turboatom steam turbines for thermal power plants]. Vestnik Nats. tekhn. un-ta "KhPI". Khar'kov, 3, 6-17 [in Russian].

5. Eremenko S. Yu. (1991). Metody konechnykh elementov $\mathrm{v}$ mekhanike deformiruemykh tel [Finite-element methods in mechanics of deformable bodies.], Khar'kov: Osnova. 271 [in Russian].

6. Gallager R. (1984) Metod konechnykh elementov. Osnovy [The finite element method. Basedata], Moscow, Mir. 428 [in Russian].

7. (2009). HITACHI. Turbine and Generator Foundation Design and construction \& recommendation. Tokyo: Japan, 104.

8. Nazarenko S. A., Tkachuk N. A (2017). Obzor nekotorykh klyuchevykh napravlenii issledovanii uchenykh NTU « KhPI» v oblasti dinamiki konstruktsii. [Review of the main directions of research of scientists of NTU "KhPI" in the field of dynamics of constructions]. Visnik NTU «KhPI», Kharkiv, 39, 49-56 [in Russian].

9. Larin A., Chumachenko O. (2016) Spivpratsya zaporiz'kikh aviadvigunobudivnikh pidpriemstv $\mathrm{z}$ providnimi vchenimi Ukraïni v galuzi dinamichnoï mitsnosti v 1950-1970-kh rr. [Cooperation
Zaporizhzhya aviation engine-building companies with the leading scientists of Ukraine in the field of dynamic strength in the 1950-1970.] Doslidzhennya $z$ istoriï tekhniki, Kharkiv, 23, 72-78 [in Ukrainian].

10. Zhovdak V. O., Krasnikov S. V., Stepchenko O. S. (2004). Reshenie zadachi statisticheskoi dinamiki ma-shinostroitel'nykh konstruktsii s uchetom slu-chainogo izmeneniya parametrov [The solution of the problem of the statistical dynamics of the machine-building constructions taking into account a random change in parameters. Kharkiv: Engineering problems]. Problemy mashinostroeniya, Kharkiv. 3, 39 - 47 [in Russian].

11. Zhiqiang $\mathrm{Hu}$, Wei Wang, Puning Jiang, Qinghua Huang, Jianhua Wang, Sihua Xu, Jin He and Lei Xiao (2014). A Seismic Analysis on Steam Turbine Con-sidering Turbine and Foundation Interaction. ASME Turbo Expo 2014: Turbine Technical Conference and Exposition, Düsseldorf. V01BT27A041, 1-8.

12. Alan Turnbull (2014). Corrosion pitting and environmen-tally assisted small crack growth. Proceedings. Mathematical, Physical, and Engineering Sciences, London: The Royal Society. 20140254, 1-19.

13. Chowdhury Indrajit, Dasguptu P. Shambhu (2009). Dynamics of Structure and foundation a unified approach. Leiden: CRC Press, 616.

14. Runov B.T. (1982) Issledovanie i ustranenie vibratsii parovykh turboagregatov [Research and elimination of the vibration of the steam turbine units], Moscow, Energoizdat. 352 [in Russian].

15. Gallager R. (1984) Metod konechnykh elementov. Osnovy [The finite element method. Basedata], Moscow, Mir. 428 [in Russian].

16. Xu X. P., Han Q. K., Chu F.L. (2016) Nonlinear vibration of a generator rotor with unbalanced magnetic pull considering both dynamic and static eccentricities. Archive of Applied Mechanics. 86, 1521-1536.

17. Jalali M. H., Ghayour M., Ziaei Rad S., Shahriari B. (2014) Dynamic analysis of a high speed rotorbearing system. Measurement: Journal of the International Measurement Confederation. 53, 19.

18. Zhang Yang, Yanlong Jiang, Guoyuan Zhang (2017) Bending fault evaluation for the HP-IP rotor system of the nuclear steam turbine based on the dynamic model. Journal of Vibroengineering. 19, 3364-3379.

19. Minli Yu,, Ningsheng Feng, Eric J. Hahn (2016) Corrigendum to" An equation decoupling approach to identify the equivalent foundation in rotatin $\mathrm{g}$ machi nery using modal parameters" $J$. Sound Vib. 365, 182 - 198.

20. Minli Yu, Jike Liu, Ningsheng Feng, Eric J. Hahn (2017) Experimental evaluation of a quasi-modal 
parameter based rotor foundation identification technique . J. Sound Vib. 411, 165 - 192.

21. Krasnikov S. V. (2017). Modelirovanie i analiz vib-ratsionnykh kharakteristik korpusa parovoi tur-biny bol'shoi moshchnosti [Modeling and analysis of the vibration characteristics of a highpower steam turbine hull]. Visnik NTU «KhPI», Kharkiv, 39, 23-26 [in Russian].

Красников Сергей Васильевич ${ }^{1}$, к.т.н., доц. каф. теоретической механики и гидравлики, тел. +38 057-707-37-30, e-mail: vsevakr@list.ru

${ }^{1}$ Харьковский национальный автомобильнодорожный университет, Украина, Харьков, 61002, ул. Ярослава Мудрого 25.

Modeling and analyzinhg vibrations of a $500 \mathrm{MW}$ turbine housing with a reduced operational frequency

Abstract. Problem. The problem of increased vibration of bodies of a steam turbine cases with a capacity of steam turbine of $500 \mathrm{MW}$ is considered. The main cause of the increased vibration of the steam turbine is the rotor's unbalance and insufficient stiffness of the system elements. The case of operating practice is considered, where the rotational alignment did not significantly change the vibration parameters. Goal. In this work the purpose was to make simulation of the forced kind of oscillations of the low-pressure cylinders flexible bodies in the turbineunit-foundation-base system with a turbine unit K-500-65/3000 KHTZ, to study the different causes of their increased level of vibration in case of less work frequencies. Methodology. The research is made using the method of oscillation, the method of finite elements, as well as the author's methods of constructing models and conducting research on oscillations of the turbineunitfoundation-base system. Results. The results of the research is as follows: a three-dimensional complex finite-element model of the turbine-foundation-base system was obtained, as well as the amplitudefrequency dependences for the points of the cylinder body of low pressure. The conducted study made it possible to draw conclusions about the different causes of increased vibration of the parts of the steam turbine unit flexible bodies. Originality. The type of designed three-dimensional models of the turbine unit-foundation-base system is unique. Due to the features of the developed model, it is possible to make a vibration processes study at a low level that enables to analyze the oscillations of complex system elements. For individual kinds of studies, further unique specification of the individual parts of the considered system is required. This enables to use the features of the finite element method to specify the turbine unit-foundation-base system in accordance with the actual operating conditions. Other researchers did not solve the problem or clarified it.
Value to practice. The significance of the work done in practical terms is primarily an illustration of the technique as a tool for developing specific models in the study of oscillations of a turbine-foundation-base system, as well as for solving practical problems of concretizing and localizing the causes of increased vibration of individual elements of a complex system. The results obtained in the work were used to improve the vibration state of the buildings of units with a steam turbine power unit with the capacity of of $500 \mathrm{MW}$.

Key words: vibration; low pressure case; steam turbine; finite element method; foundation; oscillations.

Krasnikov Sergey ${ }^{1}$, Ph.D., Assoc. Prof., tel. +38 057-707-37-30, e-mail: vsevakr@list.ru

${ }^{1}$ Kharkov National Automobile and Highway University, 25, Yaroslav Mudry street, Kharkiv, 61002, Ukraine.

Моделювання та аналіз коливань корпусу турбіни 500 МВт при зниженні робочої частоти Анотація. Вирімена практична задача з аналізу підвищеної вібрації щзодо корпусу циліндрів низького тиску парових турбін енергоблоків потужністю $500 \mathrm{MBm}$. 3'ясовано; щзо основною причиною виникнення підвищених рівнів вібрачї у паровій турбіні $\epsilon$ сили небалансу ротору; а також недостатня жорсткість серед елементів всієї системи. Розглядається наявний випадок з практиці по експлуатації енергоблоку; де центрування для роторів не надало суттєвого поліпшення робочих параметрів. В якості ијілі даної роботи було поставлено задачі 3 моделювання системи турбіна-фундаментоснова з турбіною K-500-65/3000 ХТГ3; ї̈ вимушених коливань; а також дослідження причин підвищеної вібращї корпусів циліндрів низького тиску при зменшенні значення робочої частоти. Дослідження проведено за використанням методів коливань та скінчених елементів; а також шляхом розроблених автором методик побудови моделей та досліджень коливань системи турбоагрегатфундамент-основа. За результатом проведеного дослідження були отримані: трьохвимірна скінчено-елементна модель системи турбоагрегат-фундамент-основа; амплітудночастотна залежність для системи точок $у$ корпусах ииліндрів низького тиску. Наведене дослідження дозволило надати висновки щчодо причин підвищених рівнів вібрачії верхніх частин y корпусах парової турбіни. Тип розроблених автором трьохвимірних моделей цільної системи турбоагрегат-фундамент-основа є унікальним. Завдяки наявним особливостям розробленої моделі існує реальна можливість з дослідження вібраційного процесу на рівні; щзо дозволяє аналізувати рівні вібрації всіх елементів 
системи. Для окремого дослідження потрібна конкретизація частин системи; що потребують найбільшої уваги. Це дозволяє використання особливостей методу скінчених елементів для моделювання системи турбоагрегатфундамент-основа з великим ступенем конкретизачиї реальних умов. Сторонніми дослідниками за використанням інших методик не було вирішено поставлені проблеми та вияснено конкретні причини підвішених рівнів вібрації у корпусах цииліндрів низького тиску. Практичне значення дослідження $\epsilon$ ілюстрачія засобу розробки спеціалізованої моделі для дослідження характеристик вимушених коливань у системі турбоагрегат-фундамент-основа; а також розв'язку задачі з аналізу наявних причин підвищених рівнів вібраиії. Результати роботи використано для практичних заходів; щцодо поліпшення стану вібрачій корпусів та паротурбінних установок потужністю $500 \mathrm{MBm}$. Ключові слова: вібрація; ичліндр низького тиску; парова турбіна; метод кінцевих елементів; фундамент; коливання.

Красніков Сергій Васильович'; к.т.н., доц. кафедри теоретичної механіки і гідравліки, тел. +38 057-707-37-30, e-mail: vsevakr@list.ru

${ }^{1}$ Харківський національний автомобільнодорожній університет, 61002, Україна, м. Харків, вул. Ярослава Мудрого, 25. 